\title{
Characterization of HMW glutenin subunits in European spring common wheat (Triticum aestivum L.)
}

\author{
A. Nucia $\cdot$ S. Okoń $\cdot$ M. Tomczyńska-Mleko
}

Received: 5 July 2018/Accepted: 10 December 2018/Published online: 13 February 2019

(C) The Author(s) 2019

\begin{abstract}
High molecular weight glutenin subunits plays an important role in conditioning the end-use quality of wheat products. The aim of the study was to determine the composition of HMW glutenin subunits, occurrence frequency of theses subunits and the potential of the end-use quality in spring wheat. The analysis included 81 European cultivars of spring wheat with a potential use in the food industry. Eight gene-specific markers were used to screen for HMWGS. The analyzed genotypes showed twenty-five different allelic combinations at the Glu-Al, Glu-B1 and Glu-D1 loci. The results showed that the most common at the Glu-A1 locus was Ax2* (58\%), followed by Ax1 and Axnull (the same frequency of $21 \%)$. A high variation in allelic combinations was detected at the Glu-B1 locus. The Bx7* subunit was present in $65 \%$ cultivars, $\mathrm{Bx} 7$ in $25 \%, \mathrm{Bx} 7$ or $\mathrm{Bx} 7 *$ in $7.5 \%$ and $\mathrm{Bx} 6$ in $2.5 \%$. The frequency of By9 was $59 \%$, By8-21\% and Bynull-20\%. A higher frequency of Dx5 + Dy10 (80\%) was observed at GluD1 compared to Dx2 + Dy12 (16\%) in the analyzed cultivars. A rare pattern of the Dx $5+$ Dy 12 subunits was also detected (in $4 \%$ of cultivars tested). Ax $2 *$, $\mathrm{Bx} 7 *+\mathrm{By} 9, \mathrm{Dx} 5+\mathrm{Dy} 10$ and Ax1, Bx7* + By9, Dx5 + Dy10, which determine good technological
\end{abstract}

\footnotetext{
A. Nucia $(凹) \cdot$ S. Okoń · M. Tomczyńska-Mleko Institute of Plant Genetics, Breeding and Biotechnology, University of Life Sciences in Lublin, Akademicka 15, 20-950 Lublin, Poland

e-mail: aleksandra.nucia@up.lublin.pl
}

quality in wheat, were one of the most frequently detected allelic combinations at Glu-1. The conducted analysis showed that the tested cultivars were characterized by the potentially good and very good end-use quality of wheat products. These cultivars can be used effectively in the food industry.

Keywords European spring wheat (Triticum aestivum L.) · HMW-GS · Molecular markers · PCR

\section{Introduction}

Gluten proteins play a major role in determining wheat technological properties. Two main fractions can be distinguished among them: glutenins and gliadins. Glutenins are divided into two groups: low molecular weight glutenin subunits (LMW-GS) and high molecular weight glutenin subunits (HMW-GS). The quantity and composition of glutenins are important factors in determining wheat baking properties (D'Ovidio and Masci 2004; Figueroa et al. 2009; Payne et al. 1979).

HMW-GS are encoded by three complex loci: Glu$A 1, G l u-B 1$ and Glu-Dl located near the centromeres on the long arms of group 1 chromosomes $1 \mathrm{~A}, 1 \mathrm{~B}$ and 1D. All loci have two closely linked genes that encode a higher molecular weight protein $\mathrm{x}$-type and lower molecular weight protein y-type (Payne 1987; Shewry et al. 2003). A close relationship has been demonstrated between HMW-GS composition and wheat 
baking quality (Dhaka and Khatkar 2015; Dobraszczyk and Morgenstern 2003). Typically, the Glu-Al locus encodes one or no subunits, Glu-Bl two or one and the Glu-Dl locus two subunits.

The presence of subunits encoded by the $\mathrm{D}$ genome followed by the B genome has a significant influence on good baking quality. Subunits encoded in the A genome have a lower influence on shaping these qualities (Obreht et al. 2007; Uthayakumaran et al. 2002).

The characterization of HMW-GS is an indispensable task in plant breeding aimed at the baking quality of wheat. HMW-GS variability can explain a significant part of the genetic variation affecting technological properties. Knowing the composition of HMW-GS, it is possible to make an approximate prediction of baking quality of wheat cultivars. The presence or absence of specific allelic variants of high molecular glutenins correlates with these features, and their variability depends mainly on the type of allelic variants present (Motawei 2008; Payne 1987; Song and Zheng 2007). However, it is often difficult to detect small differences between individual subunits using standard electrophoretic methods. The PCR method based on DNA markers provides an additional tool to overcome these constraints and additionally allows more accurate and faster characterization of glutenin subunit composition. A large number of PCRbased DNA molecular markers have been developed and applied on the basis of the available HMW-GS sequences. PCR-based markers are available to discriminate the important Glu-1 alleles: Dx5, Dy10, Ax2*, Bx7, Bx7*, By8 and By9 (Abdel-Mawgood 2008; Kocourkova et al. 2008; Lafiandra et al. 1997; Ma et al. 2003; Xu et al. 2008).

In the present study, we used specific DNA markers to identify Glu-1 alleles in 81 European cultivars of spring wheat. The aim of this study was to determine the frequency of occurrence of individual glutenin subunits at the Glu- 1 locus in the analyzed cultivars (Table 1).

\section{Materials and methods}

Plant material

The research material comprised 81 cultivars of spring common wheat from European breeders. The seeds of the tested cultivars were obtained from plant breeding companies from Poland (24), Czech Republic (8), Czech Republic/Denmark (4), Germany (12), Spain (4), Sweden (19), Norway (8), Sweden/Norway (1) and the United Kingdom (1) (Table 1).

\section{DNA extraction}

Genomic DNA was extracted from fresh leaf tissues using a modified CTAB method (Doyle and Doyle 1987). The quality and quantity of the isolated DNA was determined using a NanoDrop 2000 spectrophotometer. DNA samples were diluted to a working concentration of $20 \mathrm{ng} / \mu \mathrm{l}$.

PCR amplification and electrophoretic analysis

PCR reaction was performed using primers for specific genes encoding HMW-GS listed in Table 2. Amplification was carried out in a Biometra T1 thermal cycler with a heated lid in a final volume of $20 \mu \mathrm{l}$. Reaction mixture composition and cycle temperatures were determined for each primer pair after optimizing reaction conditions (Table 3 ).

The PCR products were separated by electrophoresis in a $1.5 \%$ agarose gels containing $0.1 \% \mathrm{EtBr}$ at $120 \mathrm{~V}$ for $2 \mathrm{~h}$ and visualized under a UV transilluminator and photographed using the PolyDoc System. GeneRuler $^{\mathrm{TM}} 100$ bp DNA Ladder Plus was used to determine the molecular weights of the products.

\section{Results}

The present study used eight DNA markers to determine the composition of high molecular weight glutenin subunits in 81 European cultivars of spring wheat. The PCR results are presented in Table 3.

Identification of genes at the Glu-Al locus

PCR analysis of European wheat cultivars using marker P1 produced a 920-bp fragment in 17 (21\%) cultivars, indicating the presence of the Axnull allele. This product was not amplified in the remaining 64 (79\%) cultivars, suggesting the presence of another allele at the Glu-A1 locus. Marker P2 showed the presence of one of the other two alleles: Ax1 or Ax2*. This marker generated a 1500-bp PCR product for the 
Table 1 Composition of HMW-GS in European cultivars of spring common wheat determined by PCR

\begin{tabular}{|c|c|c|c|c|c|c|c|c|c|}
\hline \multirow[t]{2}{*}{ No. } & \multirow[t]{2}{*}{ Cultivar } & \multirow[t]{2}{*}{ Origin } & \multirow[t]{2}{*}{ Year of registration } & \multicolumn{3}{|c|}{ HMW glutenin subunits } & \multicolumn{3}{|c|}{ Alleles } \\
\hline & & & & $\begin{array}{l}\text { Glu- } \\
\text { Al }\end{array}$ & Glu-B1 & $\begin{array}{l}\text { Glu- } \\
\text { D1 }\end{array}$ & $\begin{array}{l}\text { Glu- } \\
\text { A1 }\end{array}$ & $\begin{array}{l}\text { Glu- } \\
\text { B1 }\end{array}$ & $\begin{array}{l}\text { Glu- } \\
\text { D1 }\end{array}$ \\
\hline 1 & Kamelia & Poland & 2015 & Null & $7+8$ & $5+10$ & $\mathrm{c}$ & $\mathrm{b}$ & $\mathrm{d}$ \\
\hline 2 & Nimfa & Poland & 2016 & Null & 7 & $5+10$ & $\mathrm{c}$ & $\mathrm{a}$ & $\mathrm{d}$ \\
\hline 3 & Ostka Smolicka & Poland & 2010 & Null & $7^{*}+9$ & $5+10$ & $\mathrm{c}$ & $\mathrm{c}$ & $\mathrm{d}$ \\
\hline 4 & Rusałka & Poland & 2016 & Null & $7 *+9$ & $2+12$ & $\mathrm{c}$ & $\mathrm{c}$ & $\mathrm{a}$ \\
\hline 5 & Serenada & Poland & 2015 & $2 *$ & 7 & $2+12$ & $\mathrm{~b}$ & $\mathrm{a}$ & $\mathrm{a}$ \\
\hline 6 & Koksa & Poland & 2000 & 1 & $7+8$ & $5+10$ & $\mathrm{a}$ & $\mathrm{b}$ & $\mathrm{d}$ \\
\hline 7 & Korynta & Poland & 2002 & Null & $7^{*}+9$ & $2+12$ & $\mathrm{c}$ & $\mathrm{c}$ & $\mathrm{a}$ \\
\hline 8 & Nawra & Poland & 1999 & Null & $7+8$ & $5+10$ & $\mathrm{c}$ & $\mathrm{b}$ & $\mathrm{d}$ \\
\hline 9 & Harenda & Poland & 2014 & 1 & $7^{*}+9$ & $5+10$ & $\mathrm{a}$ & $\mathrm{c}$ & $\mathrm{d}$ \\
\hline 10 & Izera & Poland & 2012 & Null & $7^{*}+9$ & $5+10$ & $\mathrm{c}$ & $\mathrm{c}$ & $\mathrm{d}$ \\
\hline 11 & Parabola & Poland & 2006 & Null & 7 & $5+10$ & $\mathrm{c}$ & $\mathrm{a}$ & $\mathrm{d}$ \\
\hline 12 & Łagwa & Poland & 2009 & 1 & $7^{*}+9$ & $5+10$ & $\mathrm{a}$ & $\mathrm{c}$ & $\mathrm{d}$ \\
\hline 13 & Żura & Poland & 2002 & 1 & 7 & $2+12$ & $\mathrm{a}$ & $\mathrm{a}$ & $\mathrm{a}$ \\
\hline 14 & Rospuda & Poland & 2010 & 1 & $7^{*}+9$ & $5+10$ & $\mathrm{a}$ & $\mathrm{c}$ & $\mathrm{d}$ \\
\hline 15 & Zadra & Poland & 2005 & $2 *$ & $7 *+9$ & $2+12$ & $\mathrm{~b}$ & $\mathrm{c}$ & $\mathrm{a}$ \\
\hline 16 & Werbena & Poland & 2009 & 1 & $7^{*}+9$ & $5+10$ & $\mathrm{a}$ & $\mathrm{c}$ & $\mathrm{d}$ \\
\hline 17 & Arabella & Poland & 2011 & 1 & $7^{*}+9$ & $5+10$ & $\mathrm{a}$ & $\mathrm{c}$ & $\mathrm{d}$ \\
\hline 18 & Goplana & Poland & 2015 & Null & $7 / 7 *$ & $5+10$ & $\mathrm{c}$ & $\mathrm{a} / \mathrm{aa}$ & $\mathrm{d}$ \\
\hline 19 & Kandela & Poland & 2010 & Null & $7+8$ & $2+12$ & $\mathrm{c}$ & $\mathrm{b}$ & $\mathrm{a}$ \\
\hline 20 & Mandaryna & Poland & 2014 & 1 & $7^{*}+9$ & $2+12$ & $\mathrm{a}$ & $\mathrm{c}$ & $\mathrm{a}$ \\
\hline 21 & Struna & Poland & 2013 & 1 & 7 & $5+10$ & $\mathrm{a}$ & $\mathrm{a}$ & $\mathrm{d}$ \\
\hline 22 & Brawura & Poland & 2007 & 1 & $7 *+8$ & $5+10$ & $\mathrm{a}$ & $\mathrm{u}$ & $\mathrm{d}$ \\
\hline 23 & Katoda & Poland & 2008 & $2 *$ & $7^{*}+9$ & $5+10$ & $\mathrm{~b}$ & $\mathrm{c}$ & $\mathrm{d}$ \\
\hline 24 & Bombona & Poland & 2005 & $2 *$ & $7+8$ & $5+10$ & $\mathrm{~b}$ & $\mathrm{~b}$ & $\mathrm{~d}$ \\
\hline 25 & Alicia & Czech Republic & 2016 & 1 & $7^{*}+9$ & $5+10$ & $\mathrm{a}$ & $\mathrm{c}$ & $\mathrm{d}$ \\
\hline 26 & Alondra & $\begin{array}{l}\text { Czech Republic/ } \\
\text { Denmark }\end{array}$ & 2013 & Null & $7 *+9$ & $5+10$ & $\mathrm{c}$ & $\mathrm{c}$ & $\mathrm{d}$ \\
\hline 27 & Anabel & Czech Republic & 2014 & 1 & $7 *+9$ & $5+10$ & $\mathrm{a}$ & $\mathrm{c}$ & $\mathrm{d}$ \\
\hline 28 & Astrid & $\begin{array}{l}\text { Czech Republic/ } \\
\text { Denmark }\end{array}$ & 2012 & 1 & $6+8$ & $5+10$ & $\mathrm{a}$ & $\mathrm{d}$ & $\mathrm{d}$ \\
\hline 29 & Dafne & $\begin{array}{l}\text { Czech Republic/ } \\
\text { Denmark }\end{array}$ & 2010 & Null & $7 *+9$ & $5+10$ & $\mathrm{c}$ & $\mathrm{c}$ & $\mathrm{d}$ \\
\hline 30 & Granny & Czech Republic & 2006 & 1 & $7^{*}+9$ & $2+12$ & $\mathrm{a}$ & $\mathrm{c}$ & $\mathrm{a}$ \\
\hline 31 & Izzy & Czech Republic & 2010 & $2 *$ & $7^{*}+9$ & $5+10$ & $\mathrm{~b}$ & $\mathrm{c}$ & $\mathrm{d}$ \\
\hline 32 & Lotte & Czech Republic & 2016 & 1 & $7^{*}+9$ & $5+10$ & $\mathrm{a}$ & $\mathrm{c}$ & $\mathrm{d}$ \\
\hline 33 & Registana & Czech Republic & 2016 & 1 & $7 *+9$ & $5+10$ & $\mathrm{a}$ & $\mathrm{c}$ & $\mathrm{d}$ \\
\hline 34 & Septima & Czech Republic & 2008 & 1 & $7 *+9$ & $5+10$ & $\mathrm{a}$ & $\mathrm{c}$ & $\mathrm{d}$ \\
\hline 35 & Tercie & $\begin{array}{l}\text { Czech Republic/ } \\
\text { Denmark }\end{array}$ & 2008 & 1 & $7 *+9$ & $5+10$ & $\mathrm{a}$ & $\mathrm{c}$ & $\mathrm{d}$ \\
\hline 36 & Zuzana & Czech Republic & 2003 & 1 & $7+8$ & $5+10$ & $\mathrm{a}$ & $\mathrm{b}$ & $\mathrm{d}$ \\
\hline 37 & KWS Akvilon & Germany & 2013 & 1 & $7^{*}+9$ & $5+10$ & $\mathrm{a}$ & $\mathrm{c}$ & $\mathrm{d}$ \\
\hline 38 & KWS Buran & Germany & 2012 & Null & $7^{*}+8$ & $5+10$ & $\mathrm{c}$ & $\mathrm{u}$ & $\mathrm{d}$ \\
\hline 39 & KWS Chamsin & Germany & 2008 & 1 & $7 *+9$ & $5+10$ & $\mathrm{a}$ & $\mathrm{c}$ & $\mathrm{d}$ \\
\hline
\end{tabular}


Table 1 continued

\begin{tabular}{|c|c|c|c|c|c|c|c|c|c|}
\hline \multirow[t]{2}{*}{ No. } & \multirow[t]{2}{*}{ Cultivar } & \multirow[t]{2}{*}{ Origin } & \multirow[t]{2}{*}{ Year of registration } & \multicolumn{3}{|c|}{ HMW glutenin subunits } & \multicolumn{3}{|c|}{ Alleles } \\
\hline & & & & $\begin{array}{l}\text { Glu- } \\
\text { Al }\end{array}$ & $G l u-B 1$ & $\begin{array}{l}\text { Glu- } \\
\text { D1 }\end{array}$ & $\begin{array}{l}\text { Glu- } \\
\text { Al }\end{array}$ & $\begin{array}{l}\text { Glu- } \\
\text { B1 }\end{array}$ & $\begin{array}{l}\text { Glu- } \\
\text { D1 }\end{array}$ \\
\hline 40 & KWS Collada & Germany & 2010 & 1 & 7 & $5+10$ & a & a & $\mathrm{d}$ \\
\hline 41 & KWS Jetstream & Germany & 2015 & 1 & $7 *+9$ & $5+10$ & a & $\mathrm{c}$ & $\mathrm{d}$ \\
\hline 42 & KWS Mistral & Germany & 2015 & 1 & $7 *+9$ & $5+10$ & a & $\mathrm{c}$ & $\mathrm{d}$ \\
\hline 43 & KWS Scirocco & Germany & 2008 & Null & $7 *+9$ & $5+10$ & $\mathrm{c}$ & $\mathrm{c}$ & $\mathrm{d}$ \\
\hline 44 & KWS Solanus & Germany & 2015 & 1 & $7 *+9$ & $5+10$ & a & a & $\mathrm{d}$ \\
\hline 45 & Monsun & Germany & 2004 & 1 & $7 / 7 *$ & $5+10$ & a & $\mathrm{a} / \mathrm{aa}$ & $\mathrm{d}$ \\
\hline 46 & Taifun & Germany & 2003 & Null & $7 *+9$ & $5+10$ & $\mathrm{c}$ & $\mathrm{c}$ & $\mathrm{d}$ \\
\hline 47 & Trappe & Germany & 2005 & Null & $7 *+9$ & $5+10$ & $\mathrm{c}$ & $\mathrm{c}$ & $\mathrm{d}$ \\
\hline 48 & Vanék & Germany & 2004 & 1 & $7 *+9$ & $5+10$ & a & $\mathrm{c}$ & $\mathrm{d}$ \\
\hline 49 & Concil & Spain & 2011 & 1 & $\stackrel{7 /}{7 *}+8$ & $5+10$ & a & $\mathrm{b} / \mathrm{u}$ & $\mathrm{d}$ \\
\hline 50 & Escacena & Spain & 2002 & 1 & $7 *+9$ & $5+10$ & a & $\mathrm{c}$ & $\mathrm{d}$ \\
\hline 51 & Jerezano & Spain & 2004 & 1 & ${ }^{7 /} 7 *+8$ & $5+10$ & a & $\mathrm{b} / \mathrm{u}$ & $\mathrm{d}$ \\
\hline 52 & Tejada & Spain & 2009 & 1 & $\stackrel{7 /}{7 *}+8$ & $5+10$ & $\mathrm{a}$ & $\mathrm{b} / \mathrm{u}$ & $\mathrm{d}$ \\
\hline 53 & Vinjett & Sweden & 2001 & $2 *$ & $7 *+9$ & $5+10$ & $\mathrm{~b}$ & $\mathrm{c}$ & $\mathrm{d}$ \\
\hline 54 & Diskett & Sweden & 2009 & $2 *$ & $7 *+9$ & $5+10$ & $\mathrm{~b}$ & $\mathrm{c}$ & $\mathrm{d}$ \\
\hline 55 & Sonett & Sweden & 2010 & $2 *$ & $7 / 7 *$ & $5+10$ & $\mathrm{~b}$ & $\mathrm{a} / \mathrm{aa}$ & $\mathrm{d}$ \\
\hline 56 & Boett & Sweden & 2016 & $2 *$ & $7 *$ & $2+12$ & $\mathrm{~b}$ & aa & $\mathrm{a}$ \\
\hline 57 & Happy & Sweden & 2015 & $2 *$ & $7 *+9$ & $5+10$ & $\mathrm{~b}$ & $\mathrm{c}$ & $\mathrm{d}$ \\
\hline 58 & Berlock & Sweden & 2014 & $2 *$ & $7 *+9$ & $5+10$ & $\mathrm{~b}$ & $\mathrm{c}$ & $\mathrm{d}$ \\
\hline 59 & Miramis & Sweden & 2016 & $2 *$ & $7 *+9$ & $5+10$ & $\mathrm{~b}$ & $\mathrm{c}$ & $\mathrm{d}$ \\
\hline 60 & Countess & Sweden & 2016 & 1 & 7 & $5+12$ & a & $\mathrm{a}$ & - \\
\hline 61 & Nobless & Sweden & 2014 & 1 & $7 *+9$ & $2+12$ & a & $\mathrm{c}$ & $\mathrm{a}$ \\
\hline 62 & Crickett & Sweden & 2016 & 1 & $7 *+9$ & $5+10$ & a & $\mathrm{c}$ & $\mathrm{d}$ \\
\hline 63 & Rohan & Sweden & 2016 & 1 & 7 & $2+12$ & a & a & $\mathrm{a}$ \\
\hline 64 & Rouge & Sweden & 2016 & 1 & $7 *+9$ & $5+10$ & a & $\mathrm{c}$ & $\mathrm{d}$ \\
\hline 65 & SW 01121 & Sweden & 2001 & 1 & $7 *+9$ & $5+10$ & a & $\mathrm{c}$ & $\mathrm{d}$ \\
\hline 66 & Zebra & Sweden & 2002 & $2 *$ & $7 *+9$ & $5+10$ & $\mathrm{~b}$ & $\mathrm{c}$ & $\mathrm{d}$ \\
\hline 67 & Jack & Sweden & 2016 & 1 & $7 *+9$ & $2+12$ & a & $\mathrm{c}$ & $\mathrm{a}$ \\
\hline 68 & Bagett & Sweden & 2012 & $2 *$ & $7 *+9$ & $5+10$ & $\mathrm{~b}$ & $\mathrm{c}$ & $\mathrm{d}$ \\
\hline 69 & Dacke & Sweden & 1991 & $2 *$ & 7 & $2+12$ & $\mathrm{~b}$ & $\mathrm{a}$ & $\mathrm{a}$ \\
\hline 70 & SW Kadrilj & Sweden & 2005 & 1 & 7 & $5+10$ & a & $\mathrm{a}$ & $\mathrm{d}$ \\
\hline 71 & Kungsjet & Sweden & 2004 & 1 & 7 & $5+10$ & a & $\mathrm{a}$ & $\mathrm{d}$ \\
\hline 72 & Bjarne & Sweden/Norway & 2002 & 1 & $6+8$ & $5+10$ & a & $\mathrm{d}$ & $\mathrm{d}$ \\
\hline 73 & Berserk & Norway & 2007 & 1 & $7+8$ & $5+12$ & a & $\mathrm{b}$ & - \\
\hline 74 & Demonstrant & Norway & 2008 & 1 & $7 *+8$ & $5+10$ & a & $\mathrm{u}$ & $\mathrm{d}$ \\
\hline 75 & Krabat & Norway & 2010 & 1 & $7 *+9$ & $5+10$ & a & $\mathrm{c}$ & $\mathrm{d}$ \\
\hline 76 & Laban & Norway & 2011 & 1 & $7 *+9$ & $5+10$ & a & $\mathrm{c}$ & $\mathrm{d}$ \\
\hline 77 & Mirakel & Norway & 2012 & $2 *$ & $7 *+9$ & $5+10$ & $\mathrm{~b}$ & $\mathrm{c}$ & $\mathrm{d}$ \\
\hline 78 & Rabagast & Norway & 2013 & 1 & $7 *+8$ & $5+10$ & a & $\mathrm{u}$ & $\mathrm{d}$ \\
\hline 79 & Seniorita & Norway & 2014 & $2 *$ & $7+8$ & $5+10$ & $\mathrm{~b}$ & $\mathrm{~b}$ & $\mathrm{~d}$ \\
\hline
\end{tabular}


Table 1 continued

\begin{tabular}{|c|c|c|c|c|c|c|c|c|c|}
\hline \multirow[t]{2}{*}{ No. } & \multirow[t]{2}{*}{ Cultivar } & \multirow[t]{2}{*}{ Origin } & \multirow[t]{2}{*}{ Year of registration } & \multicolumn{3}{|c|}{ HMW glutenin subunits } & \multicolumn{3}{|c|}{ Alleles } \\
\hline & & & & $\begin{array}{l}\text { Glu- } \\
\text { Al }\end{array}$ & Glu-B1 & $\begin{array}{l}\text { Glu- } \\
\text { D1 }\end{array}$ & $\begin{array}{l}\text { Glu- } \\
\text { Al }\end{array}$ & $\begin{array}{l}\text { Glu- } \\
\text { B1 }\end{array}$ & $\begin{array}{l}\text { Glu- } \\
\text { D1 }\end{array}$ \\
\hline 80 & Willy & Norway & 2016 & 1 & $7 *+9$ & $5+12$ & $\mathrm{a}$ & $\mathrm{c}$ & - \\
\hline 81 & Tybalt & Great Britain & 2003 & Null & 7 & $5+10$ & $\mathrm{c}$ & a & $\mathrm{d}$ \\
\hline
\end{tabular}

Table 2 PCR primer sequence for the amplification of specific HMW-SG genes

\begin{tabular}{|c|c|c|c|c|c|}
\hline Locus & Gene/allele & $\begin{array}{l}\text { Primer } \\
\text { name }\end{array}$ & $\begin{array}{l}\text { Forward and reverse primer sequence }\left(5^{\prime}-\right. \\
\left.3^{\prime}\right)\end{array}$ & Product size (bp) & References \\
\hline \multirow[t]{2}{*}{$\begin{array}{r}\text { Glu- } \\
\text { Al }\end{array}$} & Axnull & $\mathrm{P} 1$ & $\begin{array}{l}\text { F: ACGTTCCCCTACAGGTACTA } \\
\text { R: TATCACTGGCTAGCCGACAA }\end{array}$ & 920 & Lafiandra et al. (1997) \\
\hline & $A x 1$ or $A x 2 *$ & $\mathrm{P} 2$ & $\begin{array}{l}\text { F: CCATCGAAATGGCTAAGCGG } \\
\text { R: GTCCAGAAGTTGGGAAGTGC }\end{array}$ & 1500 or 1400 & Lafiandra et al. (1997) \\
\hline \multirow[t]{4}{*}{$\begin{array}{r}\text { Glu- } \\
\text { B1 }\end{array}$} & $\begin{array}{l}B x 6, B x 7 \\
B x 7^{*}\end{array}$ & P3 & $\begin{array}{l}\text { F: CAAGGGCAACCAGGGTAC } \\
\text { R: AGAGTTCTATCACTGCCTGGT }\end{array}$ & $\begin{array}{l}3 \text { groups: } \\
1 \text { band of } 850-920 \\
4-5 \text { bands of } \\
420-640 \\
2 \text { bands } 180-280\end{array}$ & Butow et al. (2004) \\
\hline & $\begin{array}{l}B x 6 \\
B x 7, B x 7^{*} \\
B x 17\end{array}$ & $\mathrm{P} 4$ & $\begin{array}{l}\text { F: CGCAACAGCCAGGACAATT } \\
\text { R: AGAGTTCTATCACTGCCTGGT }\end{array}$ & $\begin{array}{l}680 \text { and } 870 \\
\sim 630 \text { and } 766 \\
669\end{array}$ & Ma et al. (2003) \\
\hline & By9 & P5 & $\begin{array}{l}\text { F: TTCTCTGCATCAGTCAGGA } \\
\text { R: AGAGAAGCTGTGTAATGCC }\end{array}$ & 662 & Lei et al. (2006) \\
\hline & $\begin{array}{l}\text { By16 } \\
\text { Bynull or } \\
\text { By } 20 \\
\text { By } 8, B y 8^{*}, \text { By } 9\end{array}$ & P6 & $\begin{array}{l}\text { F: GCAGTACCCAGCTTCTCAA } \\
\text { R: CCTTGTCTTGTTTGTTGCC }\end{array}$ & $\begin{array}{l}1 \text { band of } 290-400 \\
2 \text { bands of } 290-400 \\
3 \text { bands of } 290-400\end{array}$ & Lei et al. (2006) \\
\hline \multirow[t]{2}{*}{$\begin{array}{r}\text { Glu- } \\
\text { D1 }\end{array}$} & $D \times 5$ & P7 & $\begin{array}{l}\text { F: CGTCCCTATAAAAGCCTAGC } \\
\text { R: AGTATGAAACCTGCTGCGGAC }\end{array}$ & 478 & Ma et al. (2003) \\
\hline & Dy10 or Dy12 & P8 & $\begin{array}{l}\text { F: GTTGGCCGGTCGGCTGCCATG } \\
\text { R: TGGAGAAGTTGGATAGTACC }\end{array}$ & 576 or 612 & $\begin{array}{l}\text { Abdel-Mawgood } \\
\text { (2008) }\end{array}$ \\
\hline
\end{tabular}

Ax1 allele in 47 (58\%) cultivars and 1400-bp PCR product for the $\mathrm{Ax} 2 *$ allele in $17(21 \%)$ cultivars.

Identification of genes at the $G l u-B 1$ locus

Four DNA markers were used for the detection of alleles at the Glu-B1 locus (two pairs for "x" and "y" types).
Primer set P3 amplified 3 groups (I-III) of PCR products of different sizes. The $\mathrm{Bx} 7$ and $\mathrm{Bx} 7 *$ subunits produced 1 band of $860 \mathrm{bp}$ in group I, 4 bands of $420-600$ bp in group II and 2 bands of $180-280 \mathrm{bp}$ in group III. The PCR products for the $\mathrm{Bx} 7 *$ subunit had smaller fragments in groups II and III than the amplification products for the $\mathrm{Bx} 7$ subunit. The $\mathrm{Bx} 6$ subunit generated 1 band of $920 \mathrm{bp}$ in group I, 5 bands 
Table 3 PCR components and amplification profile

\begin{tabular}{|c|c|c|}
\hline $\begin{array}{l}\text { Primer } \\
\text { name }\end{array}$ & PCR components & Amplification cycle \\
\hline P1 & $\begin{array}{l}1 \times \text { PCR Buffer (Fermentas), } 250 \mu \mathrm{M} \text { of each dNTP, } 2 \mathrm{mM} \mathrm{MgCl}, 5 \mathrm{pM} \text { of } \\
\text { each primer, } 60 \mathrm{ng} \text { of template DNA and } 0.5 \mathrm{U} \text { Taq DNA Polymerase } \\
\text { (Fermentas) }\end{array}$ & $\begin{array}{l}1 \times 94{ }^{\circ} \mathrm{C} 5^{\prime} ; 38 \times\left(94{ }^{\circ} \mathrm{C} 1^{\prime} ; 64^{\circ} \mathrm{C} 45^{\prime \prime}\right. \\
\left.72{ }^{\circ} \mathrm{C} 1^{\prime} 30^{\prime \prime}\right) ; 1 \times 72^{\circ} \mathrm{C} 10^{\prime}\end{array}$ \\
\hline $\mathrm{P} 2$ & $\begin{array}{l}1 \times \text { PCR Buffer (Fermentas), } 250 \mu \mathrm{M} \text { of each dNTP, } 1.6 \mathrm{mM} \mathrm{MgCl}_{2}, 5 \mathrm{pM} \\
\text { of each primer, } 60 \mathrm{ng} \text { of template DNA and } 0.5 \mathrm{U} \text { Taq DNA Polymerase } \\
\text { (Fermentas) }\end{array}$ & $\begin{array}{l}1 \times 94{ }^{\circ} \mathrm{C} 5^{\prime} ; 35 \times\left(94{ }^{\circ} \mathrm{C} 1^{\prime} ; 60^{\circ} \mathrm{C} 45^{\prime \prime}\right. \\
\left.72{ }^{\circ} \mathrm{C} 1^{\prime} 30^{\prime \prime}\right) ; 1 \times 72^{\circ} \mathrm{C} 10^{\prime}\end{array}$ \\
\hline P3 & $\begin{array}{l}1 \times \text { PCR Buffer (Fermentas), } 250 \mu \mathrm{M} \text { of each dNTP, } 1.8 \mathrm{mM} \mathrm{MgCl}_{2}, 5 \mathrm{pM} \\
\text { of each primer, } 60 \mathrm{ng} \text { of template DNA and } 0.5 \mathrm{U} \text { Taq DNA Polymerase } \\
\text { (Fermentas) }\end{array}$ & $\begin{array}{l}1 \times 95^{\circ} \mathrm{C} 5^{\prime} ; 35 \times\left(94{ }^{\circ} \mathrm{C} 45^{\prime \prime} ; 58^{\circ} \mathrm{C}\right. \\
\left.45^{\prime \prime} ; 72{ }^{\circ} \mathrm{C} 1^{\prime}\right) ; 1 \times 72^{\circ} \mathrm{C} 10^{\prime}\end{array}$ \\
\hline P4 & $\begin{array}{l}1 \times \text { PCR Buffer (Fermentas), } 200 \mu \mathrm{M} \text { of each dNTP, } 1.6 \mathrm{mM} \mathrm{MgCl} \mathrm{Mg}_{2}, 5 \mathrm{pM} \\
\text { of each primer, } 60 \mathrm{ng} \text { of template DNA and } 0.5 \mathrm{U} \text { Taq DNA Polymerase } \\
\text { (Fermentas) }\end{array}$ & $\begin{array}{l}1 \times 95^{\circ} \mathrm{C} 5^{\prime} ; 35 \times\left(94{ }^{\circ} \mathrm{C} 30^{\prime \prime} ; 58^{\circ} \mathrm{C}\right. \\
\left.30^{\prime \prime} ; 72^{\circ} \mathrm{C} 2^{\prime}\right) ; 1 \times 72^{\circ} \mathrm{C} 10^{\prime}\end{array}$ \\
\hline P5 & $\begin{array}{l}1 \times \text { PCR Buffer (Fermentas), } 150 \mu \mathrm{M} \text { of each dNTP, } 1.6 \mathrm{mM} \mathrm{MgCl}_{2}, 5 \mathrm{pM} \\
\text { of each primer, } 60 \mathrm{ng} \text { of template DNA and } 0.5 \mathrm{U} \text { Taq DNA Polymerase } \\
\text { (Fermentas) }\end{array}$ & $\begin{array}{c}1 \times 95^{\circ} \mathrm{C} 2^{\prime} ; 38 \times\left(94{ }^{\circ} \mathrm{C} 30^{\prime \prime} ; 59^{\circ} \mathrm{C}\right. \\
\left.30^{\prime \prime} ; 72^{\circ} \mathrm{C} 1^{\prime} 30^{\prime \prime}\right) ; 1 \times 72{ }^{\circ} \mathrm{C} 10^{\prime}\end{array}$ \\
\hline P6 & $\begin{array}{l}1 \times \text { PCR Buffer (Fermentas), } 250 \mu \mathrm{M} \text { of each dNTP, } 1.6 \mathrm{mM} \mathrm{MgCl}_{2}, 5 \mathrm{pM} \\
\text { of each primer, } 60 \mathrm{ng} \text { of template DNA and } 0.5 \mathrm{U} \text { Taq DNA Polymerase } \\
\text { (Fermentas) }\end{array}$ & $\begin{array}{c}1 \times 95^{\circ} \mathrm{C} 5^{\prime} ; 38 \times\left(94^{\circ} \mathrm{C} 30^{\prime \prime} ; 65^{\circ} \mathrm{C}\right. \\
\left.30^{\prime \prime} ; 72^{\circ} \mathrm{C} 1^{\prime} 30^{\prime \prime}\right) ; 1 \times 72^{\circ} \mathrm{C} 10^{\prime}\end{array}$ \\
\hline P7 & $\begin{array}{l}1 \times \text { PCR Buffer (Fermentas), } 250 \mu \mathrm{M} \text { of each dNTP, } 1.8 \mathrm{mM} \mathrm{MgCl}_{2}, 5 \mathrm{pM} \\
\text { of each primer, } 60 \mathrm{ng} \text { of template DNA and } 0.5 \mathrm{U} \text { Taq DNA Polymerase } \\
\text { (Fermentas) }\end{array}$ & $\begin{array}{l}1 \times 95{ }^{\circ} \mathrm{C} 5^{\prime} ; 35 \times\left(94{ }^{\circ} \mathrm{C} 45^{\prime} ; 58{ }^{\circ} \mathrm{C} 30^{\prime \prime}\right. \\
\left.72{ }^{\circ} \mathrm{C} 1^{\prime}\right) ; 1 \times 72{ }^{\circ} \mathrm{C} 10^{\prime}\end{array}$ \\
\hline P8 & $\begin{array}{l}1 \times \text { PCR Buffer (Fermentas), } 250 \mu \mathrm{M} \text { of each dNTP, } 1.8 \mathrm{mM} \mathrm{MgCl}_{2}, 5 \mathrm{pM} \\
\text { of each primer, } 60 \mathrm{ng} \text { of template DNA and } 0.5 \mathrm{U} \text { Taq DNA Polymerase } \\
\text { (Fermentas) }\end{array}$ & $\begin{array}{l}1 \times 94{ }^{\circ} \mathrm{C} 5^{\prime} ; 40 \times\left(94{ }^{\circ} \mathrm{C} 1^{\prime} ; 63{ }^{\circ} \mathrm{C} 1^{\prime} ;\right. \\
\left.72{ }^{\circ} \mathrm{C} 1^{\prime}\right) ; 1 \times 72{ }^{\circ} \mathrm{C} 10^{\prime}\end{array}$ \\
\hline
\end{tabular}

of $420-640 \mathrm{bp}$ in group II and 2 bands of $180-280 \mathrm{bp}$ in group III. Marker P4 produced 2 bands of $\sim 630$ bp and 766 bp for cultivars containing $\mathrm{Bx} 7$ and $\mathrm{Bx} 7$ * subunits and 2 bands of $680 \mathrm{bp}$ and $870 \mathrm{bp}$ for the Bx6 allele. Similarly to primer set P3, the Bx7*subunit had smaller fragments in comparison to the $\mathrm{B} \times 7$ subunit. PCR analysis of 81 European wheat cultivars using markers $\mathrm{P} 3$ and $\mathrm{P} 4$ showed the presence of the $\mathrm{Bx} 7$ gene in $20(25 \%)$ cultivars, $\mathrm{Bx} 7 *$ in $53(65 \%)$ cultivars, $\mathrm{Bx} 7$ or $\mathrm{Bx} 7$ * in $6(7.5 \%)$ cultivars and $\mathrm{Bx} 6$ only in $2(2.5 \%)$ cultivars.

Marker P5 produced a 662-bp fragment, which turned out to be specific for the By9 gene. The remaining products suggested the presence of other By genes. The By9 allele has been identified in 48 genotypes $(58 \%)$. Primer set P6 confirmed the presence of the By9 allele in 48 cultivars. This marker generated 2 bands of 290-350 bp for this allele. Additionally, primer pair P6 allowed the identification of the By8 allele in 17 genotypes (21\%) and the Bynullallele in 16 cultivars $(20 \%)$. The By8 subunit produced 3 bands of 290-400 bp and Bynull generated 1 PCR product of $290 \mathrm{bp}$.

Identification of genes at the $G l u-D 1$ locus

Two primer sets identified the allelic composition at the Glu-D1 locus. Primers P7 was specific for the Dx5 allele and produced a 478-bp fragment. Marker P8 amplified a 576-bp PCR product for the Dy10 allele and 612-bp fragment for the Dy12 allele. The Dx5 + Dy10 composition of HMW glutenin subunits was the most frequent (80\%, 65 cultivars). The Dx $2+$ Dy 12 alleles were detected at the Glu-Dl locus in 13 cultivars $(16 \%)$. A rare $5+12$ allele was found in the remaining 3 cultivars $(4 \%)$.

\section{Discussion}

The determination of HMW-GS composition in wheat cultivar collections from different countries has been 
conducted in many studies (Atanasova et al. 2009; Brönneke et al. 2000; Henkrar et al. 2017; Jin et al. 2011; Ma et al. 2003; Moczulski and Salmanowicz 2003). The adequate composition of these proteins plays a particularly important role in conditioning the technological properties of wheat. For this reason, the determination and characterization of HMW-GS are extremely useful for assessing baking quality of wheat. Diagnostic PCR analysis with primers specific not only for individual genes, but also for nearly identical alleles of a given gene represents a valuable tool for identifying genotypes with desirable end-use quality at an early stage of breeding selection.

Three alleles, $a, b$ and $c$ (subunits $1,2^{*}$ and null) at the Glu-Al locus were identified in the studied collection of European spring wheat cultivars. Ax1 $(58 \%)$ had the highest frequency and was followed by Ax2* and Axnull (the same frequency of $21 \%$ ). The Ax1 subunit predominated in cultivars from central Europe (Poland, Czech Republic and Denmark $-40 \%$ ), but to a large extent it was also identified in cultivars from northern (34\%) and western (26\%) Europe. The Ax2* subunit was identified in cultivars from northern (71\%) and central (29\%) Europe only, while Axnull was detected in central $(71 \%)$ and western (29\%) Europe only. A similar result was obtained by Ghazy et al. (2012), who analyzed 29 cultivars of spring wheat from Saudi Arabia. They identified the Ax1 allele in $79 \%$ of screened genotypes and Ax2* occurred in $21 \%$ of tested genotypes. However, many studies reported that the Ax2* allele was the most frequent subunit at the Glu-Al locus. Jin et al. (2011) characterized HMW-GS composition for 718 cultivars and advanced lines from 20 countries. They showed the highest frequency of Ax $2 *-43.3 \%$. High frequencies of $\mathrm{Ax} 2 *$ subunit were present in cultivars from Canada, Romania, Russia and USA. Jin et al. showed low presence of Ax $2 *$ from Chile, China and Germany. In the presented work, a similar result was found no cultivar Ax2* among genotypes from Germany. The analysis carried out by Henkrar et al. (2017) was similar to the study of Jin et al. (2011). These authors identified Ax2* in $60 \%$ of Moroccan bread wheat cultivars, while $\mathrm{Ax} 1$ in $25 \%$ and Axnull in $15 \%$. The Ax 1 and Ax2* subunits at the Glu-Al locus have a significantly positive impact on the processing quality of wheat products. Their presence increases dough strength, which determines better baking quality and better quality parameter values than in wheat with the null allele (Anjum et al. 2007; Brönnekei et al. 2000; He et al. 2005; Li et al. 2010; Liang et al. 2010; Liu et al. 2005; Luo et al. 2001; Meng and Cai 2008).

Glu-1 genes show high variation. The most diverse is the Glu-B1 locus. Bx7 is one of the most important subunits encoded by the Glu-B1 locus and related to baking quality. Three variants can be distinguished among $\mathrm{Bx} 7$ : $\mathrm{Bx} 7, \mathrm{Bx} 7^{*}$ and $\mathrm{Bx} 7^{\mathrm{OE}}$. Differences between these variants are inconsiderable. The results of research carried out using primer sets P3 and P4 complemented each other and allowed for precise determination of the occurrence of individual " $x$ "type subunits. $\mathrm{Bx} 7 *$ is the most frequently identified subunit in wheat. In the present study, the $\mathrm{Bx} 7 *$ subunit occurred in $65 \%$ of the tested cultivars. $\mathrm{Bx} 7$ was identified in $25 \%$ of genotypes and $\mathrm{Bx} 7$ or $\mathrm{Bx} 7$ * (not precisely identified) - 7.5\%. A high level of $\mathrm{Bx} 7 *$ was recorded by Espí et al. (2012), Henkrar et al. (2017) and Janni et al. (2017). The Bx6 subunit is associated with poor baking quality and occurs with the relatively lowest frequency. In our study, this subunit was identified only in $2.5 \%$ of cultivars, and in the work carried out by Janni et al. (2017) only in 5\% of genotypes.

In the present study, three "y"-type subunits were identified at the Glu-Bl locus. Primer sets designed by Lei et al. (2006) were used for By subunit determination. Comparison of the results obtained for primers P5 and P6 indicated that the By9 subunit was present in $59 \%$ of cultivars, By8 in $21 \%$ and Bynull in $20 \%$ of cultivars.

Janni et al. (2017) analyzed nineteen bread wheat and twelve durum wheat cultivars. Among bread wheat cultivars, the By8 and By9 genes were identified in $16 \%$. Other "y"-type alleles were identified in the remaining cultivars. These results showed a different frequency of subunits compared to the current study. The results of research conducted by Henkrar et al. (2017) and Jin et al. (2011) were also different. The analyses carried out by Henkrar et al. (2017) showed the presence of By9 in $35 \%$ of cultivars and By 8 in 25\%. However, Jin et al. (2011) identified the By8 allele in $27.4 \%$ of all analyzed cultivars and By9 in $36.8 \%$. Among spring wheat, they found the By 8 allele in $31.1 \%$ and the By9 allele in $22.8 \%$.

In this study Bx7* + By9 was the most commonly identified allelic combination. $\mathrm{Bx} 7 *+\mathrm{By} 9$ was detected in 22 cultivars from central Europe, 16 cultivars from northern Europe and 10 cultivars from 
western Europe. Espí et al. (2012) were identified the $\mathrm{Bx} 7 *$ in $69 \%$ of tested cultivars. They draw attention to the discrimination of $\mathrm{Bx} 7, \mathrm{Bx} 7^{*}$ and $\mathrm{Bx} 7^{\mathrm{OE}}$. Espí et al. (2012) indicates several scientific papers in which insufficient attention was paid to this problem and too little detailed analysis was carried out. Many authors (Branlard et al. 2003; Morgounov et al. 1993; Ribeiro et al. 2011) have not identified the allelic composition $7 *+8$ or $7 *+9$ among several thousand varieties studied. In the light of current results, it is likely that many of them have not been correctly identified, e.g. in the study Moczulski and Salmanowicz (2003). Moczulski and Salmanowicz (2003) analysed 76 Polish cultivars and they detected the high variability within the Glu-B1 locus (Bx6 + By8$24.8 \%, \mathrm{Bx} 7+\mathrm{By} 8-13.6 \%$; Bx7-11.8\%, Bx7+ By9-43.2\%, Bx17 + By18-6.6\%), but they not identified the allelic composition $7^{*}+8$ or $7^{*}+9$. Therefore, these results can vary greatly despite the same origin of cultivars. All differences may be due to the high variability within the $G l u-B 1$ locus, country of origin or not correct identifying of subunits.

Three allelic combinations, $5+10,2+12$ and $5+12$, occurred in chromosome 1D. Many studies demonstrated that the $5+10$ subunit was dominant in relation to the $2+10$ subunit. A high frequency $(98 \%)$ of $5+10$ subunits was demonstrated by Ali et al. (2013) (in Pakistani spring wheat), $71 \%$ by Atanasova et al. (2009) (in cultivars from Bulgaria), $73 \%$ by Dias et al. (2017) (in Brazilian wheat cultivars), $85 \%$ by Henkrar et al. (2017) (in Moroccan bread wheat) and $62 \%$ by Jin et al. (2011) (in common wheat cultivars from 20 countries around the world). In our study, the analyses based on specific DNA markers for the Glu-Dl locus confirmed higher frequency of Dx5 + Dy10 (80\%) in the tested genotypes. This allelic combination was occur very frequently in all tested genotypes from northern, cental and western Europe. The $5+10$ allelic combination is associated with good baking quality, whereas the $2+10$ subunit combination conditions poor baking quality. For that reason, wheat cultivars with Dx5 + Dy10 are more desirable in wheat breeding (Abdel-Mawgood 2008; Barak et al. 2013). The Dx2 + Dy10 allelic combination was carried by $16 \%$ of cultivars. In addition, the configuration of bands indicated the presence of rare $5+12$ subunits at the Glu-D1 locus (4\%). D'Ovidio et al. (1994) has already mentioned the occurrence of $5+12$ subunits in wheat cultivars. The presence of this allelic combination was confirmed by Atanasova et al. (2009), who identified the $5+12$ allele in $2.97 \%$ of wheat cultivars. On the basis of this study and tests carried out by many authors of publications can confirm a significant advantage of $5+10$ regardless of the country of origin.

Among the wheat cultivars analyzed, 25 allelic patterns at the Glu-1 locus were identified. One of the most preferred sets of allelic combinations at Glu-1 is Glu-1A2*, Glu-1B7* + 9, Glu-1D $5+10$. In this study, 10 wheat cultivars showed the presence of this combination. However, Ax1, Bx7* + By9, Dx5 + Dy10 was the most common combination, as it was present in 23 cultivars. These two sets of alleles determine the increase in the extensibility as well as elasticity, viscosity and consistency of the dough, which in turn affects good baking quality. The remaining allelic patterns were present in single cultivars. The vast majority of the analyzed cultivars were characterized by allelic systems determining good or very good baking quality, indicating the suitability of these cultivars in the food industry.

\section{Compliance with ethical standards}

Conflict of interest The authors declare that they have no conflict of interest.

Ethical approval This article does not contain any studies with human participants or animals performed by any of the authors.

Informed consent The authors agreed to the publication of the manuscript. All authors read and approved the final manuscript.

Open Access This article is distributed under the terms of the Creative Commons Attribution 4.0 International License (http:// creativecommons.org/licenses/by/4.0/), which permits unrestricted use, distribution, and reproduction in any medium, provided you give appropriate credit to the original author(s) and the source, provide a link to the Creative Commons license, and indicate if changes were made.

\section{References}

Abdel-Mawgood AL (2008) Molecular markers for predicting end-products quality of wheat (Triticum aestivum L.). Afr J Biotechnol 7:2324-2327

Ali N, Iqbal M, Yasmin S, Ahmed I, Asif M (2013) Genetic variation in loci controlling quality traits in spring wheat. Pak J Agric Sci 50:637-647 
Anjum FM, Khan MR, Din A, Saeed M, Pasha I, Arshad MU (2007) Wheat gluten: high molecular weight glutenin subunits-structure, genetics, and relation to dough elasticity. J Food Sci 72:R56-R63

Atanasova D, Tsenov N, Todorov I, Ivonova I (2009) Glutenin composition of winter wheat varieties bred in Dobrudzha Agricultural Institute. Bulg J Agric Sci 15:9-19

Barak S, Mudgil D, Khatkar BS (2013) Relationship of gliadin and glutenin proteins with dough rheology, flour pasting and bread making performance of wheat varieties. LWT Food Sci Technol 51:211-217

Branlard G, Dardevet M, Amiour N, Igrejas G (2003) Allelic diversity of HMW and LMW glutenin subunits and omegagliadins in French bread wheat (Triticum aestivum L.). Genet Resour Crop Evol 50:669-679

Brönneke V, Zimmermann G, Killermann B (2000) Effect of high molecular weight glutenins and D-zone gliadins on breadmaking quality in German wheat varieties. Cereal Res Commun 28:187-194

Butow BJ, Gale KR, Ikea J, Juhász A, Bedö Z, Tamás L, Gianibelli MC (2004) Dissemination of the highly expressed Bx7 glutenin subunit (Glu-B1al allele) in wheatas revealed by novel PCR markers and HPLC. Theor Appl Genet 109:1525-1535

D'Ovidio R, Masci S (2004) The low-molecular-weight glutenin subunits of wheat gluten. J Cereal Sci 39:321-339

D'Ovidio R, Porceddu E, Lafiandra D (1994) PCR analysis of genes encoding allelic variants of high-molecular-weight glutenin subunits at the Glu-D1 locus. Theor Appl Genet $88: 175-180$

Dhaka V, Khatkar BS (2015) Effects of gliadin/glutenin and HMW-GS/LMW-GS ratio on dough rheological properties and bread-making potential of wheat varieties. J Food Qual 38:71-82

Dias RO, Souza MA, Pirozi MR, Oliveira LC, Pimantel AJB (2017) Protein profile and molecular markers related to the baking quality of Brazilian wheat cultivars. Cereal Chem 94:568-575

Dobraszczyk BJ, Morgenstern MP (2003) Rheology and the breadmaking process. J Cereal Sci 38:229-245

Doyle JJ, Doyle JL (1987) A rapid DNA isolation procedure for small quantities of fresh leaf tissue. Phytochem Bull 19:11-15

Espí A, Giraldo P, Rodriguez-Quijano M, Carrillo JM (2012) A PCR-based method for discriminating between high molecular weight glutenin subunits $\mathrm{Bx} 7$ and $\mathrm{Bx} 7$ * in Triticum aestivum L. Plant Breed. https://doi.org/10.1111/j. 1439-0523.2012.01961.x

Figueroa JDC, Maucher T, Reule W, Peña RJ (2009) Influence of high molecular weight glutenins on viscoelastic properties of intact wheat kernel and relation to functional properties of wheat dough. Cereal Chem 86:139-144

Ghazy AI, Zanouny AI, Moustafa KA, Al-Doss AA (2012) Molecular screening of high molecular weight glutenin genes in spring bread wheat genotypes in Saudi Arabia. J Food Agric Environ 10:157-161

He ZH, Liu L, Xia XC, Liu JJ, Peña RJ (2005) Composition of HMW and LMW glutenin subunits and their effects on dough properties, pan bread, and noodle quality of Chinese bread wheats. Cereal Chem 82:345-450
Henkrar F, El-Haddoury J, Iraqi D, Bendaou N, Udupa SM (2017) Allelic variation at high-molecular weight and lowmolecular weight glutenin subunit genes in Moroccan bread wheat and durum wheat cultivars. 3 Biotech 7:287

Janni M, Cadonici S, Pignone D, Marmiroli N (2017) Survey and new insights in the application of PCR-based molecular markers for identification of HMW-GS at the Glu-B1 locus in durum and bread wheat. Plant Breed 136:467-473

Jin H, Yan J, Peña RJ, Xia XC, Morgounov A, Han LM, Zhang Y, He ZH (2011) Molecular detection of high- and lowmolecular-weight glutenin subunit genes in common wheat cultivars from 20 countries using allele-specific markers. Crop Pasture Sci 62:746-754

Kocourková Z, Bradová J, Kohutová Z, Slámová L, Vejl P, Horčička P (2008) Wheat breeding for the improved breadmaking quality using pcr based markers of glutenins. Czech J Genet Plant Breed 44:105-113

Lafiandra D, Tucci GF, Pavoni A, Turchetta T, Margiotta B (1997) PCR analysis of x-and y-type genes present at the complex Glu-A1 locus in durum and bread wheat. Theor Appl Genet 94:235-240

Lei ZS, Gale KR, He ZH, Gianibelli C, Larroque O, Xia XC, Butow BJ, Ma W (2006) Y-type gene specific markers for enhanced discrimination of high-molecular weight glutenin alleles at the Glu-B1 locus in hexaploid wheat. J Cereal Sci 43:94-101

Li Y, Zhou R, Branlard G, Jia J (2010) Development of introgression lines with 18 alleles of glutenin subunits and evaluation of the effects of various alleles on quality related traits in wheat (Triticum aestivum L.). J Cereal Sci 51:127-133

Liang D, Tang J, Peña RJ, Singh R, He X, Shen X, Yao D, Xia X, He Z (2010) Characterization of CIMMYT bread wheats for high- and low-molecular weight glutenin subunits and other quality-related genes with SDS-PAGE, RP-HPLC and molecular markers. Euphytica 172:235-250

Liu L, He Z, Yan J, Zhang Y, Xia X, Peña RJ (2005) Allelic variation at the Glu-1 and Glu-3 loci, presence of the 1B.R translocation, and their effects on mixographic properties in Chinese bread wheats. Euphytica 142:197-204

Luo C, Griffin WB, Branlard G, McNeil DL (2001) Comparison low- and high molecular-weight wheat glutenin alleles effects on flour quality. Theor Appl Genet 102:1088-1098

Ma W, Zhang W, Gale KR (2003) Multiplex-PCR typing of high molecular weight glutenin alleles in wheat. Euphytica 134:51-60

Meng XG, Cai SX (2008) Association between glutenin alleles and Lanzhou alkaline stretched noodle quality of northwest China spring wheats. II. Relationship with the variations at the Glu-1 loci. Cereal Res Commun 36:107-115

Moczulski M, Salmanowicz B (2003) Multiplex-PCR identification of wheat HMW glutenin subunit genes by allelespecific markers. J Appl Genet 44:459-471

Morgounov AI, Crossa J, Rajaram S (1993) Worldwide distribution of Glu-1 alleles in bread wheat. J Genet Breed 47:53

Motawei MI (2008) Molecular weight glutenin alleles at the Glu-B1 locus. G3 2:53-56

Obreht D, Kobiljski B, Djan M, Vapa L (2007) Identification of Glu-B1 alleles in bread wheat cultivars using PCR. Genetika 39:23-28 
Payne PI (1987) Genetics of wheat storage proteins and the effect of allelic variation on bread-making quality. Ann Rev Plant Physiol 38:141-153

Payne PI, Corfield KG, Blackman JA (1979) Identification of a high-molecular-weight subunit of glutenin whose presence correlates with bread-making quality in wheats of related pedigree. Theor Appl Genet 55:153-159

Ribeiro M, Carvalho C, Carnide V, Guedes-Pinto H, Igrejas G (2011) Towards allelic diversity in the storage proteins of old and currently growing tetraploid and hexaploid wheats in Portugal. Genet Resour Crop Evol 58:1051-1073

Shewry PR, Halford NG, Lafiandra D (2003) Genetics of wheat gluten proteins. Adv Genet 49:111-184
Song Y, Zheng Q (2007) Dynamic rheological properties of wheat flour dough and proteins. Trends Food Sci Technol 18:132-138

Uthayakumaran S, Beasley HL, Stoddard FL, Keentok M, PhanThien N, Tanner RI, Békés F (2002) Synergistic and additive effects of three high molecular weight glutenin subunit loci, I. Effects on wheat dough rheology. Cereal Chem 79:294-300

Xu Q, Xu J, Liu CL, Chang C, Wang CP, You MS, Li BY, Liu GT (2008) PCR-based markers for identification of HMWGS at Glu-B1x loci in common wheat. J Cereal Sci 47:394-398 